Простий інтерфейс, завдання різних форматів, які доповнюють теоретичний матеріал, анімаційний і звуковий супровід покращують засвоєння інформації, а також роблять можливим використання посібника для роботи зі школярами з вадами зору та слуху.

Отже, одним із основних інструментів розвитку суспільства $є$ освіта з використанням електронних технологій, яка сприяє швидкому й змістовному оновленню форм і засобів, технологій та методів навчання, формуванню в учнів навичок, актуальних для сьогодення (критично мислити та швидко ухвалювати рішення; виявляти творчість, креативність та новаторство; бути комунікативним і готовим до співробітництва тощо) [5].

Зазначимо, що впровадження та викладання курсу вимагає застосування певних форм і методів роботи з учителями. Залучення вчителів до участі в семінарах, творчих групах, узагальнення передового педагогічного досвіду сприяє популяризації фінансових знань і формуванню економічної свідомості самого вчителя, зростанню його вмотивованості до поширення фінансової освіти.

Висновки. Отже, навчально-методичне забезпечення предмета - передумова засвоєння навчального матеріалу учнями у школі. Від того, наскільки розробленими є всі складники навчально-методичного комплексу із фінансової грамотності залежить наповнюваність навчально-методичного комплекту для вчителя й учня та результативність навчання зокрема.

Перспективи подальших досліджень. Для якісної організації освітнього процесу із фінансової грамотності доцільним є постійне оновлення його навчально-методичного забезпечення, основу якого становить сучасний підручник. Добір таких його додатків (творчо-інтелектуальних завдань, медіатек із цікавою інформацією, електронних додатків), які відповідали б запитам сучасного учня, $є$ важливим організаційно-дидактичним завданням. Центром моделей розвитку закладів освіти нового типу є творча особистість.
3 огляду на це, перспективами подальших розвідок у цьому напрямі $\epsilon$, зокрема, оформлення банку запитань компетентнісного спрямування із фінансової грамотності.

\section{СПИСОК ВИКОРИСТАНОЇ ЛІТЕРАТУРИ}

1. Економіка \& фінанси для учнів 9 класу // Лист Інституту інноваційних технологій і змісту освіти від 29.05.2015 № 14.1 / 12-Г-332.

2. Фінансова грамотність. 10 клас : інтерактивний електронний посібник / за заг. редакцією Т. С. Смовженко // Лист IITЗО від 28.03.2014 № 14.1 / 12-Г-480.

3. Програми 3 курсу «Фінансова грамотність» на 35 та 105 годин / за заг. ред. д. е. н., проф. Т. С. Смовженко // Наказ Міністерства освіти і науки України від 18.09.2014 № 1054 .

4. Наказ МОН від 12.10.2015 № 1069 «Про проведення апробації та моніторингових досліджень якості інтерактивного електронного посібника 3 курсу «Фінансова грамотність» для загальноосвітніх навчальних закладів та вищих навчальних закладів I - II рівнів акредитації України у 2015/2016/2017 навчальних роках».

5. Прикладні фінанси для учнів 8 класу // Лист Інституту інноваційних технологій і змісту освіти від 29.05.2015 № 14.1 / 12-Г-331.

6. Родинні фінанси для учнів 5 класу // Лист Інституту інноваційних технологій і змісту освіти від 29.05.2015 № 14.1 / 12-Г-328.

7. Фінансова абетка для учнів 2 класу // Лист МОН від 20.05.2015 № 1/ 11-7119.

8. Фінансова арифметика для учнів 3 класу // Лист МОН від 20.05.2015 № 1 / 11-7118.

9. Фінансова культура для учнів 7 класу // Лист Інституту інноваційних технологій і змісту освіти від 29.05.2015 № 14.1 / 12-Г-330.

10. Фінансова поведінка для учнів 4 класу // Лист МОН від 20.05.2015 № 1 / 11-7117.

Дата надходження до редакиії: 06.06.2019 р.
УДК 37.07:005.4:37.091.4

DOI: $10.37026 / 2520-6427-2019-99-3-36-41$
Микола ЛЮШИН, кандидат педагогічних наук, завідувач кабінету освітнього адміністрування, доиент кафедри філософії, економіки та менеджменту освіти Рівненського ОІППО

\title{
СИСТЕМА УПРАВЛІННЯ СУЧАСНИМ ЗАКЛАДОМ ОСВІТИ В КОНТЕКСТІ ПЕДАГОГІЧНОЇ СПАДЩИНИ В. О. СУХОМЛИНСЬКОГО
}

У статті на основі аналізу наукового доробку В. О. Сухомлинського досліджено сутність управління закладом загальної середньої освіти як складовоі педагогічної системи. Окреслено пріоритетні напрями впровадження ідей видатного украӥния світового рівня в сучасну управлінську практику.
Ключові слова: директор (керівник) школи, заклад освіти, менеджмент, нова українська школа, педагогічна система, педагогічна спадшина, система управління, В. О. Сухомлинський. 
В статье на основе анализа научного наследия В. А. Сухомлинского исследована сущнность управления учреждением общего среднего образования как составляющей педагогической системы. Определены приоритетные направления внедрения идей выдаюшегося украиниа мирового уровня в современную управленческую практику.

Ключевые слова: директор (руководитель) школь, учебное заведение, менеджмент, новая украинская школа, педагогическая система, педагогическое наследие, система управления, В. А. Сухомлинский.

The development of Ukrainian national education actualizes the creative heritage of the outstanding Ukrainian teacher V. O. Sukhomlynsky. He turned the normal rural school in a unique teaching laboratoryknown in the world under the names of "School of joy", "School under the blue sky» together with his colleagues. An appeal to the pedagogical creativity of the director-innovator allows us systematically consider the administrative processes of the modern institution of general secondary education from the standpoint of its humanistic concept and competent management.

The goal of this article is to separate and analyze the views of scientist and practice in the field of management as a component of the educational system, to show their relevance for new schools and further scientific developments.

On the basis of the analysis of $V . O$. Sukhomlynsky's scientific work, the essence of the institution of general secondary education as a component of the original pedagogical system was investigated. The scientist approaches to realization of key management functions, in particular analysis, planning, organization and control are revealed. The functional field of activities of the subjects of the educational management process is determined, namely: the director (head) of the school, the pedagogical council as a permanent collegiate governing body, and bodies of public self-government. In the dialogue with V. O. Sukhomlynsky's pedagogical heritage, priority directions of the implementation of the prominent Ukrainian of world-class level's ideas in the newest administrative practice were outlined.

Our research is an attempt to comprehend $V$. O. Sukhomlynsky's pedagogical experience in terms of the realities of modern education management. Study of $V$. O. Sukhomlynsky's pedagogical heritage gives grounds to assert that the unique experience of the great teacher corresponds to the main tendencies of the formation and new Ukrainian school's development. Because the purpose of it is to create an interesting, life-oriented education with democratic management practices at all levels.

Further scientific quest is to be connected with creating of the author's pedagogical systems and models of educational institutions of the region in the context of innovative ideas of $V$. O. Sukhomlynsky, checking their effectiveness by means of pedagogical experiment and an innovative educational project.

Key words: director (head) of school, educational institution, management, new Ukrainian school, pedagogical system, pedagogical heritage, management system, V. O. Sukhomlynsky.
Постановка проблеми. Розбудова української національної освіти відзначається інтенсивними пошуками продуктивних шляхів створення ефективної системи управління закладом освіти. Примітно, що ця проблема актуалізує творчу спадщину славетного українського педагога-гуманіста В. О. Сухомлинського (1918-1970), який разом зі своїми колегами перетворив звичайну сільську школу в неповторну педагогічну лабораторію, справжню скарбницю педагогічної мудрості. Упродовж 22 років В. О. Сухомлинський очолював Павлиську середню школу Онуфріївського району Кіровоградської області [1, с. 10, 21], відому у світі як «Школа радості», «Школа під блакитним небом». Достатньо сказати, що книжка «Серце віддаю дітям» [8], в якій вжито ці визначення, надрукована більше 50 мовами світу. Глибоке захоплення в сучасних керівників освіти викликає книжка «Павлиська середня школа» [6], яка містить повний опис діяльності шкільного колективу, його тісної взаємодії із громадою села Павлиш. Звернення до педагогічної творчості В. О. Сухомлинського дозволяє нам системно розглянути управлінські процеси сучасного закладу загальної середньої освіти (далі - закладу ЗСО) з позицій його гуманістичної концепції та компетентного управління.

Аналіз наукових досліджень та публікацій. Управлінські аспекти наукового і творчого доробку В. О. Сухомлинського як суттєву складову педагогічних пошуків XX століття розглядали М. Я. Антонець, Ю. О. Грицай, Н. В. Єрмак, Н. А. Калініченко, Л. М. Кравченко, Т. О. Кузьміч, Н. С. Луцюк, С. Ф. Одайник, І. Є. Остапйовський, О. В. Сараєва, Т. М. Сорочан, Б. П. Хижняк та ін. Відома дослідниця авторської управлінської лабораторії А. І. Постельняк відзначає, що «В. О. Сухомлинському як досвідченому керівникові було властиве системне бачення школи як складної динамічної системи, що постійно розвивається та вдосконалюється за умови компетентного управління» [3, с. 9].

Наше дослідження є спробою осмислення педагогічної спадщини В. О. Сухомлинського з погляду реалій сучасного менеджменту освіти. Зважаючи на це, визначаємо мету статті: виокремити і проаналізувати погляди вченого-практика у сфері управлінської діяльності як складової педагогічної системи, продемонструвати їх актуальність для нової української школи та подальших наукових розробок.

Виклад основного матеріалу. Системний підхід як методологічна основа розвитку пізнання оточуючої дійсності, як найбільш поширений науковий підхід у соціально-педагогічних дослідженнях та практиці передбачає розгляд управління закладом освіти з позицій цілісної динамічної складної системи. Н. М. Островерхова стверджує: «... поняття «система» $\mathrm{i}$ «система управління» детермінуються наявністю елементів та відношень чи взаємодії між ними. Суть системи зумовлює структуру і функціональну спрямованість іiі елементів. За характером зв'язки між елементами системи бувають різними: вони можуть виражати відношення, взаємодію, побудову, функціональне спрямування» [2, с. 6]. Тому педагогічну систему ми розглядаємо як цілісне утворення, що спрямоване на досягнення соціально значущої 
педагогічної мети та складається із компонентів і структурних елементів, які взаємодіють, взаємодоповнюють один одного. У нашому дослідженні акцентовано увагу на функціональній взаємодії, тобто органічній єдності ключових функцій суб'єктів процесу управління закладом ЗСО.

Відповідно до статті 24 Закону України «Про освіту» [4] система управління закладом освіти визначається законом та установчими документами. Управління закладом освіти здійснюють: засновник (засновники); керівник закладу освіти; колегіальний орган управління закладу освіти; колегіальний орган громадського самоврядування; інші органи, передбачені спеціальними законами та/або установчими документами закладу.

Безпосереднє керівництво закладом ЗСО здійснює директор у межах, наданих йому законом, статутом закладу освіти та строковим трудовим договором повноважень. Керівник державного, комунального закладу ЗСО призначається на посаду рішенням засновника (засновників) закладу або уповноваженого ним (ними) органу за результатами проведення конкурсу на посаду.

Основним постійно діючим колегіальним органом управління закладу ЗСО (структурного підрозділу закладу, що забезпечує здобуття загальної середньої освіти) є педагогічна рада. Педагогічна рада планує роботу закладу, схвалює освітню програму закладу, оцінює результативність іiї виконання, формує систему та затверджує процедури внутрішнього забезпечення якості освіти, затверджує щорічний план підвищення кваліфікації педагогічних працівників, розглядає інші питання, пов'язані з діяльністю закладу. Повноваження педагогічної ради деталізують Закон України «Про загальну середню освіту» та установчі документи закладу освіти.

Згідно зі статтею 28 Закону України «Про освіту» [4] громадське самоврядування в закладі освіти можуть уособлювати: органи самоврядування працівників закладу освіти (основним $є$ загальні збори трудового колективу закладу освіти); органи самоврядування здобувачів освіти, що можуть мати різноманітні форми і назви; органи батьківського самоврядування (в межах класу, закладу освіти, за інтересами тощо); інші органи громадського самоврядування учасників освітнього процесу. Вищим колегіальним органом громадського самоврядування закладу освіти є загальні збори (конференція) колективу закладу освіти. Однак сьогодні рішення про створення учнівських та/або батьківських комітетів (як органів управління закладом) усе ще приймає сам заклад на загальних зборах (конференціiі) колективу. Тому наявність (відсутність) відповідних органів не залежить від бажання здобувачів освіти або батьків.

Управління закладом ЗСО здійснює також піклувальна рада, яка створюється за рішенням засновника відповідно до статті 29 Закону України «Про освіту» [4]. До складу піклувальної ради закладу освіти не можуть входити здобувачі освіти та працівники цього закладу. На сьогодні в багатьох закладах освіти ще працюють ради закладів, зміст діяльності яких визначають їх статути. Аналіз практики засвідчує, що функціональна здатність та реальний вплив цих громадських структур на ухвалення певних рішень $\mathrm{i}$ вектор розвитку школи залишаються недостатніми, а то й формальними.

Ефективне керівництво закладом освіти можливе за наявності високого рівня науково-педагогічної підготовки, загальної ерудиції, професіоналізму членів адміністрації, вчителів, інших спеціалістів. Сповідуючи ідеї компетентного управління закладом освіти, В. О. Сухомлинський наголошував: «Суть керівництва сучасною школою полягає в тому, щоб у найважчій справі виховання на очах учителів створювався, визрівав і утверджувався кращий досвід, який втілює в собі передові педагогічні ідеї. I той, хто $є$ творцем цього досвіду, чия праця стає зразком для інших вихователів, - той і повинен бути директором школи. Без такого директора - кращого вихователя - не можна собі уявити в наші дні школу» [8, с. 12-13]. Проте вчений-педагог застерігав: «Керівництво школою - це насамперед педагогічне керівництво і лише поряд із цим - адміністративне» [7, c. 424].

В. О. Сухомлинський у книжці «Розмова з молодим директором школи» [7] визначав поле діяльності керівника закладу освіти з таких позицій: 1) директорце насамперед педагог, і педагог першокласний; 2) якщо ви хочете бути хорошим директором, намагайтеся передусім стати гарним педагогом, гарним вихователем «не лише щодо тих дітей, яких ви навчаєте на своїх уроках, але й щодо всіх вихованців школи, довіреної вам суспільством, народом, батьками. Якщо ж ви, зайнявши посаду директора, вважаєте, що успіх залежить від якихось особливих адміністративних талантів, прощайтеся 3 думкою стати хорошим директором» [7, с. 398]; 3) директор-садівник (метафоричне бачення ролі керівника): він із любов'ю обробляє землю, яка дає життя, і робить будь-який паросток культурним; 4) зв'язок управління із процесами самоорганізації дитячого та дорослого товариства сприяє тому, що зникає проблема опору, з'являються добровільність, відповідальність, інтерес.

Своє бачення мав В. О. Сухомлинський щодо реалізації ключових функцій управління, зокрема планування. Керівник-дослідник уважав за доцільне розробляти перспективний план роботи школи на тривалий період - 10 років, розрахований на повний цикл навчання дитини, а перспективний план роботи класного керівника - на чотири-шість років його виховної роботи з класом. Розробити план - це означає спроектувати комплекс заходів, спрямованих на покращення навчально-виховної роботи та iii результативність. Водночас Василь Олександрович зауважував, що поурочний план є обов'язковим документом, який має відображати індивідуальну творчу лабораторію вчителя. «Нема якогось стандарту поурочного плану. $\mathcal{C}$ певні вимоги, які ставляться до нього. Це насамперед дидактична обробка теоретичного матеріалу, який учням належить засвоїти. Поурочний план учителя, який працює творчо, - це максимальне передбачення того, що повинно бути, і того, що може виникнути на уроці», - констатував учений [7, с. 453]. 
Не менш важливою в менеджменті В. О. Сухомлинського була організаторська функція, зокрема щодо формування та розвитку педагогічного колективу на засадах партнерства, взаємної доброзичливості, творчої співпраці. Цю стратегію управлінських дій він зорієнтовував насамперед на раціональну організацію роботи педагогічної ради, уміле визначення змісту iii роботи. Відповідаючи на запитання «Як спланувати роботу педагогічної ради, як добитися того, щоб педагогічна рада була колективним органом керівництва школою?», директор-наставник радив керівникам шкіл: «Починайте з найпростішого. Нехай усі вчителіі початкових, і середніх, і старших класів - подумають над питанням: яка залежність мислення, думки школярів від уміння читати? Нехай думають про це всі учителі, спостерігаючи за розумовою працею школярів. Нехай усі заглиблюються думкою в цю цікаву залежність» [7, с. 404]. На засіданнях педагогічної ради розглядалися такі питання, як: «Специфіка проведення уроків у перші дні навчального року», «Урок заключного повторення і систематизації знань», «Забезпечення індивідуального підходу до учнів на уроках», «Розвиток логічного мислення учнів на уроках у початковій школі» та ін. «Жодних найскладніших суперечок із учителем я ніколи не виносив на засідання педагогічної ради <..>; індивідуальна, дружна, відверта, душевна розмова - головний метод роботи директора з учителем», - писав В. О. Сухомлинський [3, с. 12].

Особливу зацікавленість викликає практична реалізація академічної (освітньої) автономії як імперативу управлінської діяльності. В. О. Сухомлинський устами вчителя математики Павлиської школи звертав увагу на запоруку дотримання принципу академічної свободи: «Я вважаю дуже важливою умовою успіху те, щоб мету, яку треба досягти у викладанні предмета, ставив не тільки педагог, а й самі учні. Якщо розумова праця є бажаною для учня, він прагне досягти поставленої мети не для того, щоб дістати високу оцінку своєї праці, а головним чином для того, щоб пережити радість відкриття істини» [5, с. 107]. Поділяємо позицію В. О. Сухомлинського і щодо політики академічної доброчесності: «... кращі учні вважають за ганьбу користуватися наслідками розумової праці своїх товаришів (списувати тощо). Для них це неприпустимо насамперед тому, що використання результатів чужої праці принижує людську гідність» [5, с. 107]. Отже, внутрішня свобода в роботі завжди має морально-етичний вимір.

3 огляду на це значущою є діяльність В. О. Сухомлинського як директора, менеджера, лідера школи щодо забезпечення участі батьківської громадськості у спільному вирішенні проблем розвитку закладу освіти. У Павлиській школі була створена «... педагогічна школа для батьків, у ній відділи: дошкільний, батьків учнів I-III класів, IV-VIII класів, IX-X класів. За три роки до того, як віддати своїх дітей до навчання, мати й батько починають вчитися в педагогічній школі для батьків. Два рази на місяць вони слухають лекції директора школи, заступника директора із навчально-виховної роботи, заступника із позакласної роботи, вчителя, який через три роки навчатиме I клас» [9, с. 536].
А вчителям, класним керівникам В. О. Сухомлинський давав таку настанову: «Учіть батьків мистецтва виховання як найблагороднішої, найлюдянішої, найвищої творчості, як виконання високого громадянського обов'язку» [9, с. 537]. Не менш вартісні для сьогодення його настанови класним керівникам дотримуватися гуманної взаємодії з батьками, зокрема $з$ тими, що допускають помилки і прорахунки у вихованні: «... якщо ви почнете «вивертати душі», виставляти на загальний огляд людську біду (а невміння виховувати це передусім біда), до вас приходитиме все менше й менше батьків, ви відштовхнете їх від школи...» $[9$, с. 537-538].

Не втратили актуальності в наш час педагогічні ідеї В. О. Сухомлинського щодо покликання школи як громадської, виховної установи «активно впливати на середовище, створювати сприятливу для виховання атмосферу» [7, с. 503]; розвитку учнівського самоврядування - «зробіть правилом морального виховання: нехай ваш виховний задум здійснюється активною діяльністю самих учнів» [7, с. 557]; «не нав'язувати їм грубо своїх думок, терпляче вислуховувати їхні висловлювання (іноді навіть і неправильні!), вступати з ними в суперечку як рівний з рівним» [6, с. 21]. Розроблена система відповідальних доручень у Павлиській школі передбачала створення низки форм самодіяльних органів: комітету з охорони природи, комітету з охорони грунту, групи підлітків $з$ охорони рибного господарства, групи сприяння бджільництву та ін.

Значну увагу В. О. Сухомлинський приділяв зростанню професійної майстерності вчителя, реалізації його творчого потенціалу. Він радив керівникам шкіл пробудити в учителя «інтерес до творчого осмислення власної праці» [7, с. 400], «допомогти кожному вчителеві в створенні індивідуальної творчої лабораторії» $[6$, с. 72], постійно спонукати його «шукати щось нове, думати над удосконаленням своєї майстерності» [7, с. 405] у вимірі практичного втілення прогресивних педагогічних ідей і технологій. Повчальним для сучасних керівників освіти $€$ досвід В. О. Сухомлинського щодо здійснення контрольно-аналітичної діяльності, зокрема оцінювання роботи вчителя. У книжці «Розмова 3 молодим директором школи» у спеціальному розділі «Поради про відвідування та аналіз уроків» він зазначав: «Директор відвідує й аналізує уроки не тільки для того, щоб учити вчителів, давати їм поради. Педагогічна лабораторія школи - це творча єдність всіх учителів, повсякденне інтелектуальне збагачення, взаємний обмін духовними цінностями... Аналіз системи уроків потрібний для того, щоб побачити й осмислити саму суть педагогічних явищ та їх причинно-наслідкові зв'язки. У процесі відвідування й аналізу системи уроків найкраще розкриваються основні залежності педагогічного процесу - умови міцних, глибоких знань і причини поверховості знань» [7, с. 578-579]. Щороку директор Павлиської школи відвідував 350-400 уроків, під час яких він контролював і результативність власної індивідуальної роботи з учителем, з'ясовував правильність, дієвість своїх висновків, порад, рекомендацій [3, с. 16]. 
Керівника школи, який відвідує за рік 70-80 уроків, а то й менше, він образно порівнював із людиною, що «приходить на роботу із зав'язаними очима i блукає, як у пітьмі: щось чує, але нічого не бачить, не знає, не розуміє» $[7$, с. 578]. Показовим у цьому зв'язку і гідним для наслідування є приклад управлінської культури: «Коли я йду на урок, то думаю про те, щоб учитель спокійно вів урок, а коли розмовляю з учителем, аналізуючи його урок, то думаю про те, щоб учитель спокійно провів ніч» [1, с. 178]. Погоджуємося 3 видатним педагогом, що дотримання педагогічної етики, грунтованої на засадах гуманізму, поваги до особистості, є неодмінною складовою і педагогічної культури («місія педагога полягає передусім у тому, щоб захистити дитину від насильства над тілом і душею» $[10$, с. 306]). Саме такі кваліфіковані підходи дають можливість успішно поєднувати теорію і практику менеджменту освіти, приймати оптимальні управлінські рішення, робити наукові узагальнення про взаємозалежність структурних компонентів освітнього та управлінського процесів.

У діалозі з педагогічною спадщиною В. О. Сухомлинського усвідомлюємо важливість розв'язання низки сучасних освітніх проблем, які є актуальними для суспільства та привабливими для споживачів освітніх послуг: 1) створення безпечного та психологічно комфортного освітнього середовища, вільного від будь-яких форм насильства і дискримінації. За визначенням ученого, «середовище не є чимось раз назавжди створеним і незмінним. Середовище повинно повсякденно створюватися і збагачуватися. <..> Середовище повинно не тільки спонукати до активної діяльності, а й стримувати, гальмувати» [7, с. 549-550]; 2) формування готовності керівника закладу освіти як креативного менеджера, маркетолога, лідера організації до системних змін; 3) організація освітнього процесу на засадах людиноцентризму (орієнтації на потреби людини); академічної, організаційної, фінансової і кадрової автономії закладу освіти; 4) запровадження системи внутрішнього забезпечення якості освіти, втілення політики академічної доброчесності; 5) відкриття спектра можливостей для постійного професійного розвитку педагогічних працівників, здатних оволодівати методиками компетентнісного навчання та найпродуктивнішими сучасними освітніми технологіями; 6) налагодження конструктивної співпраці учасників освітнього та управлінського процесів, взаємодії закладу освіти з місцевою громадою на основі довіри, прозорості й інформаційної відкритості.

Висновки. Отже, вивчення педагогічної спадщини В. О. Сухомлинського дає підстави стверджувати, що вченому вдалося органічно поєднати безцінні практичні знахідки з їх науковим осмисленням. Відійшовши від ідеологічних догм авторитарної педагогіки, він створив на засадах гуманістичної концепції та компетентного управління оригінальну педагогічну систему, адекватну реальній дійсно- сті. Унікальний досвід великого педагога відповідає провідним тенденціям становлення і розвитку нової української школи, мета якої - створення цікавої, зорієнтованої на життя освіти 3 демократичними практиками управління на всіх рівнях. Саме тому науково-педагогічні ідеї В. О. Сухомлинського заслуговують вдумливого вивчення й інтерпретації як наукової, так і практико-технологічної.

Перспективи подальших досліджень убачаємо в проектуванні авторських педагогічних систем і моделей закладів освіти регіону в контексті педагогічного новаторства В. О. Сухомлинського та перевірці їх ефективності шляхом проведення дослідно-експериментальної роботи.

\section{СПИСОК ВИКОРИСТАНОЇ ЛІТЕРАТУРИ}

1. Антонець М. Я. Сучасні проблеми діяльності вчителя у педагогічній спадщині Василя Сухомлинського : монографія / М. Я. Антонець. Вид. 8-е, доп. - Рівне : Волинські обереги, 2018. $308 \mathrm{c}$.

2. Островерхова Н. М. Теоретичні засади технологій управління загальноосвітнім навчальним закладом як активною соціально-педагогічною системою [Електронний ресурс] / Н. М. Островерхова // Освіта та розвиток обдарованої особистості. 2015. - № 8. - C. 5-12. URL: http://nbuv.gov.ua/UJRN/ Otros_2015_8_3 (дата звернення: 01.07.2019).

3. Постельняк А. І. Проблеми управління школою у спадщині В. Сухомлинського / А. І. Постельняк // Управління школою. - 2013. - № 10/12. C. $8-24$.

4. Про освіту : Закон України від 05.09.2017 № 2145-VIII [Електронний ресурс]. URL: http://zakon2.rada.gov.ua/laws/show/2145-19 (дата звернення: 01.07.2019).

5. Сухомлинський В. О. Сдність навчальної і виховної мети / В. О. Сухомлинський // Вибрані твори : в 5-ти т. - К. : Радянська школа, 1976. - Т. 2. С. $102-109$.

6. Сухомлинський В. О. Павлиська середня школа / В. О. Сухомлинський // Вибрані твори : в 5-ти т. К. : Радянська школа, 1977. - Т. 4. - С. 5-390.

7. Сухомлинський В. О. Розмова з молодим директором школи / В. О. Сухомлинський // Вибрані твори : в 5-ти т. - К. : Радянська школа, 1977. - Т. 4. С. 391-626.

8. Сухомлинський В. О. Серце віддаю дітям / В. О. Сухомлинський // Вибрані твори : в 5-ти т. - К. : Радянська школа, 1977. - Т. 3. - С. 5-279.

9. Сухомлинський В. О. Сто порад учителеві / В. О. Сухомлинський // Вибрані твори : в 5-ти т. - К. : Радянська школа, 1976. - Т. 2. - С. 417-654.

10. Сухомлинський В. О. Як любити дітей / В. О. Сухомлинський // Вибрані твори : в 5-ти т. - К. : Радянська школа, 1977. - Т. 5. - С. 292-308.

Дата надходження до редакиї: 17.07.2019 р. 